\title{
Słuchowo-językowe funkcjonowanie dzieci bilateralnie zaimplantowanych wszczepem ślimakowym w trybie sekwencyjnym, doniesienie wstępne
}

\begin{abstract}
Magdalena Magierska-Krzysztoń, Stuchowo-językowe funkcjonowanie dzieci bilateralnie zaimplantowanych wszczepem ślimakowym w trybie sekwencyjnym, doniesienie wstepne [Audio-linguistic functioning of children bilaterally implanted with cochlear implants in the sequential mode, a preliminary report]. Interdyscyplinarne Konteksty Pedagogiki Specjalnej, nr 18, Poznań 2017. Pp. 115-130. Adam Mickiewicz University Press. ISSN 2300-391X

Severe hearing damage in the prenatal period or when the baby is born is a disability that significantly impairs the correct functioning in the society of hearing people. A particularly perceptible consequence of severe hearing impairment is the lack or significant delay in the development of speech and language acquisition. Thanks to the use of cochlear implants, the Program of Surgical Treatment of Deafness With the Method of Cochlear Implantation allows children with perceptive deafness for the access to speech sounds through the auditory pathway. It gives them an opportunity to develop speech and language and in the future - the ability to satisfactorily communicate with other people. The study covered 54 born-deaf children, bilaterally implanted in the sequential mode. The implantation was performed at the Department of Otolaryngology and Laryngological Oncology of the Poznan University of Medical Sciences. The results indicate a constant, dynamic increase of auditory and linguistic-communication skills in the examined group.
\end{abstract}

KEY WORDS: audio-linguistic skills, deaf children, bilateral implantation with cochlear implants in the sequential mode 


\section{Wstęp}

Sprawnie działający słuch jest jednym ze zmysłów, dzięki którym dziecko eksploruje rzeczywistość. Jest narzędziem, za pomocą którego można odkryć język, nauczyć się komunikować z innymi ludźmi. Prawidłowe słyszenie warunkuje nie tylko percepcję mowy na drodze słuchowej oraz rozumienie komunikatów kierowanych pośrednio i bezpośrednio do nas, lecz także umożliwia kontrolę własnych produkcji wokalnych. Jeszcze w życiu płodowym mózg dziecka, $w$ toku ontogenezy, zostaje przygotowany do zwracania uwagi na mowę ludzką. Przysłuchiwanie się językowi dźwiękowemu, którym komunikują się inni ludzie, już w kilku pierwszych miesiącach życia dziecka wystarcza, aby struktury nerwowe odpowiedzialne za umiejętność rozumienia i tworzenia funkcjonalnych konstrukcji językowych doskonaliły się ${ }^{1}$. Głębokie uszkodzenie słuchu powstałe $\mathrm{w}$ okresie prelingwalnym jest bardzo poważną niepełnosprawnością. Może ograniczać kontakt z innymi ludźmi, a w konsekwencji uniemożliwić pełny, harmonijny rozwój dziecka.

Brak rozwoju języka służącego do komunikacji oraz budowania „mowy wewnętrznej” skutkuje narastaniem procesów deprywacji informacyjnej, co prowadzi do ograniczeń w rozwoju poznawczym. Pojawiające się trudności $\mathrm{w}$ funkcjonowaniu społecznym oraz problemy psycho-emocjonalne dotyczące umiejętności interpretowania świata i postaw innych osób z najbliższego otoczenia może skutkować u dziecka, a później młodego niesłyszącego człowieka poczuciem izolacji, wyobcowania, lęku oraz wycofania. Dlatego tak ważne jest, aby jak najwcześniej wykryć i zdiagnozować głuchotę oraz zaburzenia słuchu, aby zminimalizować negatywne konsekwencje funkcjonalnych ograniczeń. Szybka diagnoza oraz interwencja medyczna skutkująca zaopatrzeniem dziecka $w$ aparaty słuchowe daje szansę na rozpoczęcie oddziaływań rehabilitacyjnych przed upływem okresu krytycznego dla rozwoju danej funkcji, czyli okresu maksymalnej podatności i plastyczności układu nerwowego na

${ }^{1}$ A. Smith, Umyst, PZWL, Warszawa 1989, s. 121-125. 
określone bodźce płynące ze środowiska. Pierwsze lata życia dziecka stanowią fundament w jego rozwoju psychoruchowym i emocjonalnym, ten czas jest również istotny dla procesu nabywania mowy i języka. Gdy ubytek słuchu jest tak duży, że klasyczne aparatowanie będzie niewystarczające, aby uzyskać możliwość percepcji dźwięków na drodze słuchowej, istnieje możliwość zastosowania implantu ślimakowego. Program Chirurgicznego Leczenia Głuchoty Metodą Wszczepów Ślimakowych dedykowany jest osobom z głębokim, obustronnym niedosłuchem odbiorczym. Przeciwskazaniem do implantacji jest zarośnięcie ślimaka oraz anomalie anatomiczne w uchu wewnętrznym, które może wykryć tylko specjalistyczne badanie: tomografia komputerowa lub rezonans magnetyczny. Implant ślimakowy umożliwia odbiór dźwięków otoczenia, w tym mowy i poprzez stymulację akustyczno-elektryczną dostarcza bodźce do ośrodków słuchowych w centralnym układzie nerwowym, gdzie są one odbierane jako wrażenia słuchowe2. Sprawnie działający mózg uczy się interpretować i nadawać znaczenie docierającym bodźcom. Dzieciom $\mathrm{z}$ głuchotą prelingwalną, u których zmysłowy dostęp do mowy i języka na drodze słuchowej jest praktycznie niemożliwy, implant ślimakowy daje możliwość wykrywania, różnicowania i rozróżniania, identyfikacji, a w końcu rozumienia dźwięków mowy. Zastosowanie tej techniki nie jest jednak w pełni wystarczające do tego, aby dziecko rozwijało samodzielnie umiejętności słuchowe i mowne. Konieczne jest prowadzenie systematycznej, zaplanowanej terapii, której podstawą jest wychowanie słuchowe. Zazwyczaj podjęcie decyzji o wszczepieniu implantu ślimakowego swojemu niesłyszącemu dziecku rodzice podejmują szybko, mając nadzieję, że zastosowanie tej chirurgicznej metody da możliwość odkrycia świata bogatego w doznania akustyczne. Mają też nadzieję, że w ten sposób dziecko dostanie szansę na „bycie normalnym", takim samym jak reszta otoczenia. Upowszechnienie wiedzy, że szybka implantacja, przeprowadzona tak wcześnie jak to

${ }^{2}$ H. Skarżyński, Wszczepy ślimakowe, [w:] Zarys audiologii klinicznej, red. A. Pruszewicz, Poznań 2000, s. 517. 
tylko możliwe, pozwala dziecku niesłyszącemu na rozwój zbliżony do dzieci w normie słuchowej i powoduje, że często podejmują oni decyzję szybko, kierując się emocjami, nie mając sprecyzowanych oczekiwań wobec implantu i całego procesu rehabilitacji pooperacyjnej. Dlatego zdarzają się głębokie rozczarowania spowodowane faktem, że implant ślimakowy nie przywraca w cudowny sposób słyszenia, a proces nabywania umiejętności słuchowych i mownych jest bardzo żmudny i nie zawsze przynosi wyczekiwane efekty.

$W$ takiej sytuacji rodzice dzieci jednostronnie zaimplantowanych zaczynają rozważać możliwość wszczepienia drugiej protezy. W Klinice Otolaryngologii Uniwersytetu Medycznego w Poznaniu decyzję o bilateralnej implantacji podejmuje się, biorąc pod uwage wskazania medyczne: inne dysfunkcje (na przykład zespół Ushera lub duża wada wzroku) oraz np. brak wymiernych korzyści z użytkowania jednej protezy. Proces podejmowania decyzji o wszczepieniu drugiego implantu powoduje różne dylematy wśród rodziców: czy zaopatrzyć w drugi implant dziecko, które w pierwszej protezie bardzo dobrze funkcjonuje słuchowo i językowo, czy też wręcz przeciwnie - wspomóc drugim implantem takie dziecko, które z różnych względów nie ma możliwości wykorzystania dobrodziejstw pierwszej protezy? Badania naukowe prowadzone w wielu ośrodkach implantujących na całym świecie wskazują wyraźnie, że przy spełnieniu m.in. warunków dotyczących prawidłowej terapii, dzieci posiadające wszczep ślimakowy są w stanie rozumieć mowę w zestawach otwartych wyłącznie na drodze słuchowej, a język funkcjonalny rozwija się w wystarczający sposób do komunikacji ${ }^{3}$. Bilateralna implantacja może dodatkowo poprawić rozumienie mowy w warunkach trudnych akustycznie oraz umożliwić precyzyjną lokalizację usłyszanych dźwięków oraz przyczynić się do poprawy jakości słyszenia przestrzennego ${ }^{4}$. Poprawa komfortu

${ }^{3}$ B. Szagun, The acquisition of grammatical and lexical structures in children with cochlear implants: a development psycholinguistic approach, "Audiol Neurootol" 2000, 5, s. 39-47.

4 J. Sarant, D. Harris, L. Bennet, S. Bant, Bilateral versus unilateral cochlear implants in children: a study of spoken language outcomes, „Ear Hear” 2014, Jul.-Aug., 35(4), s. 396-409. 
i jakości "dwuusznego" słyszenia w dwóch implantach ślimakowych otwiera nowe możliwości przed użytkownikami systemu. Dla małego dziecka, być może jeszcze niedoświadczonego słuchowo, te nowo uzyskane zdolności są bezcenne i mogą pozytywnie wpłynąć na poziom uspołecznienia oraz jakość codziennego życia. Implantacja bilateralana może odbyć się w trybie symultanicznym, kiedy to wszczepienie dwóch implantów odbywa się jednocześnie i zazwyczaj dotyczy to pacjentów po przebytym zapaleniu opon mózgowych lub $w$ innych przypadkach uzasadnionych medycznie. $\mathrm{W}$ warunkach polskich najczęściej podejmowaną formą $\mathrm{w}$ ramach realizacji Programu Leczenia Głuchoty Metodą Wszczepów Ślimakowych jest implantacja w trybie sekwencyjnym, co oznacza, że od przeprowadzenia jednej operacji do momentu podjęcia decyzji o drugiej musi upłynąć minimum rok. Decyzję podejmuje zespół specjalistów, biorąc pod uwagę wyniki testów psychologiczno-pedagogiczno-logopedycznych oraz indywidualne predyspozycje i wskazania medyczne.

\section{Materiał i metody}

W badaniach wzięło udział 54 dzieci z głuchotą prelingwalną, zaimplantowanych bilateralnie $\mathrm{w}$ trybie sekwencyjnym. Operacje wszczepienia pierwszego i drugiego implantu ślimakowego przeprowadzono w Klinice Otolaryngologii i Onkologii Laryngologicznej Uniwersytetu Medycznego im. Karola Marcinkowskiego w Poznaniu. Wszystkie badane dzieci do momentu implantacji użytkowały aparaty słuchowe. U około 30\% zaobserwowano przed pierwszą operacją spontaniczne realizacje wokalne, które nie miały jednak odzwierciedlenia w systemie językowym. Wszystkie badane dzieci były w normie intelektualnej, u trójki dzieci zdiagnozowano i później potwierdzono zaburzenia ze spektrum autyzmu, czworo dzieci - dużą wadę wzroku. Badana grupa dzieci zaimplantowanych bilateralnie była grupą homogenną, użytkującą wszczep ślimakowy Nucleus, firmy Cochlear. Wszystkie dzieci wychowywały się w ro- 
dzinach osób prawidłowo słyszących i posługujących się na co dzień mową dźwiękową. Badana grupa swój pierwszy implant otrzymała między 18. miesiącem a 5. rokiem życia. Dzieci w chwili badania stanowiły zróżnicowaną grupę pod względem wieku fizjologicznego: 70\% stanowiły dzieci między 7. a 10. rokiem życia, a pozostałe $30 \%$, to dzieci między 10. a 18. rokiem życia.

Dzieci objęte były systematyczną terapią logopedyczną w miejscu zamieszkania, w placówce edukacyjnej, do której uczęszczały lub w najbliższej okolicy. Łączny czas użytkowania jednego implantu, który jest równoznaczny z czasem pooperacyjnej rehabilitacji, wynosił 2-17 lat (tabela 1), a czas, który upłynął pomiędzy jedną a drugą implantacją to minimum rok, a maksymalnie trzynaście lat. Czas równoczesnego korzystania już z dwóch aktywnych wszczepów ślimakowych wynosił minimum 18 miesięcy do nawet sześciu lat (tabela 2).

Tabela 1. Czas użytkowania wszczepu ślimakowego u wszystkich pacjentów - jednostronna implantacja

\begin{tabular}{|l|c|}
\hline \multicolumn{1}{|c|}{$\begin{array}{c}\text { Czas użytkowania jednego wszczepu } \\
\text { ślimakowego }\end{array}$} & Liczba pacjentów \\
\hline Od 2 do 7 lat & 33 \\
\hline Od 7 do 12 lat & 15 \\
\hline Powyżej 12 lat & 6 \\
\hline
\end{tabular}

Tabela 2. Czas użytkowania dwóch wszczepów ślimakowych równocześnie (od momentu podłączenia drugiego implantu) - bilateralna implantacja $\mathrm{w}$ trybie sekwencyjnym

\begin{tabular}{|l|c|}
\hline $\begin{array}{c}\text { Czas użytkowania dwóch wszczepów } \\
\text { ślimakowych }\end{array}$ & Liczba pacjentów \\
\hline Od 18 miesięcy do 3 lat & 30 \\
\hline Od 3 do 5 lat & 21 \\
\hline Powyżej 5 lat & 3 \\
\hline
\end{tabular}


W badaniach posłużono się testem TAPS (Test of Auditory Perception of Speech), przetłumaczonym i dostosowanym do warunków języka polskiego w Katedrze Chorób Ucha, Nosa, Gardła i Krtani Uniwersytetu Medycznego w Poznaniu oraz w Zakładzie Fonetyki Akustycznej PAN w Poznaniu. Test daje możliwość sprawdzenia jak dziecko słyszy i rozumie dźwięki mowy w zestawach zamkniętych i otwartych. Badanie przeprowadzono w trudnych warunkach akustycznych, przy udziale dźwięków zakłócających. Dzieci wykonywały zadania testowe podczas użytkowania jednego wszczepu (drugi implant wyłączony) oraz w dwóch działających implantach. Wszyscy pacjenci mieli stabilne mapy słuchowe wygenerowane podczas sesji programowania procesora mowy. Dodatkowo posłużono się Arkuszem Badania Umiejętności Językowych, który powstał w ośrodku poznańskim. Arkusz bada podstawowe umiejętności językowe $\mathrm{w}$ zakresie rozumienia, produkcji mowy, zasobu pojęć oraz świadomości fonologicznej, niezbędnej do tworzenia prawidłowych wzorców artykulacyjnych realizowanych wokalnie.

\section{Wyniki}

Wszystkie badane dzieci użytkujące system przez minimalny czas bezbłędnie wykonują test wykrywania fonemów na drodze słuchowej zarówno w jednym, jak i w dwóch implantach. Wyniki uzyskane $\mathrm{w}$ teście TAPS poziom II również pokazują, że wszyscy pacjenci, funkcjonując już $w$ jednym implancie, opanowali percepcje wzorców rytmicznych mowy na drodze słuchowej przy udziale dźwięków zakłócających, co jest niezbędne do wykształcenia umiejętności rozróżniania i różnicowania elementów suprasegmentalnych mowy zarówno w wypowiedziach słyszanych, jak i produkcjach własnych (tabela 3). Wyniki wcześniejszych badań wskazują, że dzieci potrzebują na to przeciętnie około sześciu miesięcy5. Jedy-

${ }^{5}$ W. Szyfter, A. Pruszewicz i wsp., Ocena zachowań stuchowych dzieci postugujących się wszczepem ślimakowym, „Otolaryngologia Polska” 1997, Tom L, Supl. 22, s. 200-204. 
nie pacjenci ze współistniejącymi deficytami rozwojowymi, które mogą wpływać na opóźnienie tworzenia się schematów poznawczych, potrzebują na ten proces nieco więcej czasu - około roku do dwóch lat ${ }^{6}$.

Tabela 3. Test TAPS, poziom II (słuchanie w szumie)

\begin{tabular}{|l|c|}
\hline \multicolumn{1}{|c|}{ Pacjenci zaimplantowani } & Percepcja wzorców rytmicznych mowy \\
\hline Odsłuch w jednym implancie & $100 \%$ \\
\hline Odsłuch w dwóch implantach & $100 \%$ \\
\hline
\end{tabular}

Tabela 4. Test TAPS, poziom III (słuchanie w szumie)

\begin{tabular}{|c|c|c|c|c|c|c|}
\hline \multirow{3}{*}{$\begin{array}{l}\text { Percepcja cech } \\
\text { mowy, identy- } \\
\text { fikacja mowy }\end{array}$} & \multicolumn{3}{|c|}{$\begin{array}{l}\text { Liczba pacjentów - odsłuch } \\
\text { w } 1 \text { implancie }\end{array}$} & \multicolumn{3}{|c|}{$\begin{array}{l}\text { Liczba pacjentów - odsłuch } \\
\text { w } 2 \text { implantach }\end{array}$} \\
\hline & \multicolumn{3}{|c|}{ czas użytkowania CI } & \multicolumn{3}{|c|}{ czas użytkowania CI } \\
\hline & $\begin{array}{l}\text { od } 2 \text { do } \\
7 \text { lat }\end{array}$ & $\begin{array}{l}\text { od } 7 \text { do } \\
12 \text { lat }\end{array}$ & $\begin{array}{c}\text { powyżej } \\
12 \text { lat }\end{array}$ & $\begin{array}{c}\text { od } 18 \\
\text { miesięcy } \\
\text { do } 3 \text { lat }\end{array}$ & $\begin{array}{l}\text { od } 3 \text { do } \\
5 \text { lat }\end{array}$ & $\begin{array}{l}\text { powyżej } \\
5 \text { lat }\end{array}$ \\
\hline $70 \%>$ & 20 & 15 & 6 & 25 & 21 & 3 \\
\hline $50 \%$ & 11 & - & - & 5 & - & - \\
\hline $50 \%<$ & 2 & - & - & - & - & - \\
\hline
\end{tabular}

Wyniki uzyskane w dalszej części testu TAPS, poziom III, percepcja cech mowy, identyfikacja mowy pokazują, że dzieci bilateralnie zaimplantowane, ze stażem użytkowania implantów nawet 18-miesięcznym, radzą sobie nieco lepiej z zadaniami językowymi, których wysłuchują w wygenerowanym sztucznie szumie o natężeniu około 40 dB. Im dłuższy czas funkcjonowania w dwóch implan-

${ }^{6}$ W. Szyfter, J. Kaczmarek i wsp., Czy mnogie uszkodzenia uniemożliwiaja zastosowanie wszczepów wewnątrzślimakowych, Rehabilitacja w Otologii Materiały zjazdowe, Poznań 8-10.10.1998. 
tach, tym wyniki odsłuchów u dzieci z włączonym jednym i drugim implantem stają się bardzo podobne (tabela 4).

Podczas prowadzonego badania zauważyć można było, że identyfikacja na drodze słuchowej wyrazów/zwrotów o jednakowej liczbie sylab sprawiała dzieciom najwięcej trudności. W tym przypadku rola domysłu nie była tak istotna jak poziom kompetencji językowej, będący wyznacznikiem czynnego funkcjonowania w języku. Po raz kolejny zaobserwować można było, że im dłuższy staż użytkowania implantu/implantów tym lepsze wyniki w tym zakresie. Widać to wyraźnie na poziomie IV testu TAPS, kiedy oczekiwano od dzieci rozpoznawania i rozumienia mowy podawanej ze zbiorów zamkniętych i otwartych (tabele 5 i 6 ).

Tabela 5. Test TAPS, poziom IV (słuchanie w szumie)

\begin{tabular}{|l|c|c|c|c|c|c|}
\hline \multirow{2}{*}{$\begin{array}{c}\text { Rozpoznawa- } \\
\text { nie, rozumie- } \\
\text { nie mowy, } \\
\text { zbiory za- } \\
\text { mknięte }\end{array}$} & \multicolumn{3}{|c|}{$\begin{array}{c}\text { Liczba pacjentów - odsłuch } \\
\text { w 1 implancie }\end{array}$} & \multicolumn{2}{|c|}{$\begin{array}{c}\text { Liczba pacjentów - odsłuch } \\
\text { w 2 implantach }\end{array}$} \\
\cline { 2 - 7 } & 7 lat & $\begin{array}{c}\text { czas użytkowania CI } \\
\text { od } 2 \text { do do }\end{array}$ & $\begin{array}{c}\text { cowyżej } \\
12 \text { lat }\end{array}$ & $\begin{array}{c}\text { czas użytkowania CI } \\
\text { miesięcy } \\
\text { do 3 lat }\end{array}$ & $\begin{array}{c}\text { od 3 do } \\
5 \text { lat }\end{array}$ & $\begin{array}{c}\text { powyżej } \\
5 \text { lat }\end{array}$ \\
\hline $70 \%>$ & 20 & 14 & 6 & 22 & 20 & 3 \\
\hline $50 \%$ & 10 & 1 & - & 7 & 1 & - \\
\hline $50 \%<$ & 3 & - & - & 1 & - & - \\
\hline
\end{tabular}

Tabela 6. Test TAPS - poziom IV (słuchanie w szumie)

\begin{tabular}{|l|c|c|c|c|c|c|}
\hline \multirow{2}{*}{$\begin{array}{c}\text { Rozpoznawa- } \\
\text { nie, rozumie- } \\
\text { nie mowy, } \\
\text { zbiory otwarte }\end{array}$} & \multicolumn{3}{|c|}{$\begin{array}{c}\text { Liczba pacjentów - odsłuch } \\
\text { w 1 implancie }\end{array}$} & \multicolumn{2}{|c|}{$\begin{array}{r}\text { Liczba pacjentów - odsłuch } \\
\text { w 2 implantach }\end{array}$} \\
\cline { 2 - 7 } & 7 lat do & $\begin{array}{c}\text { czas użytkowania CI } \\
\text { od do lat }\end{array}$ & $\begin{array}{c}\text { powyżej } \\
12 \text { lat }\end{array}$ & $\begin{array}{c}\text { od } 18 \\
\text { miesięcy } \\
\text { do 3 lat }\end{array}$ & $\begin{array}{c}\text { od 3 do } \\
5 \text { lat }\end{array}$ & $\begin{array}{c}\text { powyżej } \\
5 \text { lat }\end{array}$ \\
\hline $70 \%>$ & 20 & 14 & 6 & 22 & 19 & 3 \\
\hline $50 \%$ & 10 & 1 & - & 6 & 2 & - \\
\hline $50 \%<$ & 3 & - & - & 2 & - & - \\
\hline
\end{tabular}


Odbiór oraz interpretacja materiału testowego na tym poziomie wymaga zarówno biernej znajomości, jak i czynnego posługiwania się językiem funkcjonalnym we wszystkich aspektach: semantycznym, syntaktycznym, morfologicznym oraz fonologicznym. I tutaj zaobserwować można dysproporcje w wynikach pomiędzy słyszeniem i rozumieniem w jednym i w dwóch implantach. Pacjenci implantowani bilateralnie z czasem użytkowania dwóch implantów powyżej trzech lat radzili sobie najlepiej z tą kategorią testu, wysłuchiwaną w warunkach analogicznych do pozostałych etapów, tzn. trudnych akustycznie, z udziałem czynników zakłócających. Analiza pozostałych wyników uzyskanych podczas badania Arkuszem Umiejętności Językowych pokazuje, że ta grupa dzieci zaimplantowanych bilateralnie i użytkujących wszczepy pięć, a nawet więcej lat osiąga najlepsze wyniki w wszystkich badanych sferach funkcjonowania językowego (tabela 7).

Tabela 7. Arkusz Badania Umiejętności Językowych

\begin{tabular}{|l|c|c|c|c|c|c|}
\hline \multirow{2}{*}{$\begin{array}{c}\text { Umiejętności } \\
\text { językowo- } \\
\text {-komunikacyjne }\end{array}$} & \multicolumn{3}{|c|}{ Odsłuch w 1 implancie } & \multicolumn{3}{c|}{ Odsłuch w 2 implantach } \\
\cline { 2 - 7 } & $\begin{array}{c}\text { od 2 do lat } \\
7 \text { lat }\end{array}$ & $\begin{array}{c}\text { od 7 do } \\
12 \text { lat }\end{array}$ & $\begin{array}{c}\text { powyżej } \\
12 \text { lat }\end{array}$ & $\begin{array}{c}\text { od 18 } \\
\text { miesięcy } \\
\text { do 3 lat }\end{array}$ & $\begin{array}{c}\text { od 3 do } \\
5 \text { lat }\end{array}$ & $\begin{array}{c}\text { powyżej } \\
5 \text { lat }\end{array}$ \\
\hline Rozumienie & $58 \%$ & $70 \%$ & $90 \%$ & $56 \%$ & $70 \%$ & $90 \%$ \\
\hline Produkcja mowy & $53 \%$ & $65 \%$ & $75 \%$ & $60 \%$ & $70 \%$ & $75 \%$ \\
\hline Zasób pojęć & $45 \%$ & $60 \%$ & $70 \%$ & $58 \%$ & $65 \%$ & $72 \%$ \\
\hline Artykulacja & $65 \%$ & $80 \%$ & $85 \%$ & $70 \%$ & $75 \%$ & $90 \%$ \\
\hline
\end{tabular}

Analizując wyniki uzyskane przez poszczególnych badanych, zauważyć można, że największe opóźnienia występują w sferze produkcji mowy. Aby komunikacja z innymi była satysfakcjonująca, konieczne jest posługiwanie się adekwatnymi do danej sytuacji społecznej modelami językowymi, które należy kreatywnie modyfikować w oparciu o znajomość reguł gramatycznych. Słownictwo, które jest dobierane i używane w określonych sytuacjach, związane jest 
z zasobem pojęć, którym dysponują poszczególni pacjenci. Tutaj również zaobserwować można, że dzieci używające dwóch implantów, ale tylko te $z$ długim czasem użytkowania obu wszczepów (minimum cztery lata) uzyskują nieco lepsze wyniki w wyżej wymienionej sferze podczas odsłuchów w porównaniu do tych uzyskanych $\mathrm{w}$ jednym implancie. Bogaty zasób pojęć jest związany z procesem prawidłowego interpretowania rzeczywistości, a brak możliwości analizy współwystępujących akustycznych cech (związany z indywidualnym czasem trwania głuchoty) przedmiotów, ludzi, zwierząt i różnych zjawisk, może upośledzić proces kształtowania się pojęć, co spowoduje nawarstwianie się dalszych trudności i opóźnień w rozwoju mowy i języka. Porównywalne wyniki osiągnęli pacjenci funkcjonujący w jednym i w dwóch implantach podczas prezentowanych zadań testowych w sferze umiejętności artykulacyjnych. Związane może to być z faktem, że terapię pacjentów zaimplantowanych jeszcze $\mathrm{w}$ wielu placówkach prowadzą logopedzi ogólni, którzy są najlepiej przygotowani do pracy z pacjentami wymagającymi korekty deficytów mowy na poziomie realizacji prawidłowych wzorców artykulacyjnych. Efektem takich oddziaływań jest uzyskanie wyrazistszej wymowy, która jest bardziej zrozumiała dla otoczenia, lecz taka terapia ma niewiele wspólnego $\mathrm{z}$ całościowym oddziaływaniem surdologopedycznym prowadzonym w sferze językowo-komunikacyjnej. Wyniki przeprowadzonych badań wskazują, że dzieci zaimplantowane osiągają lepsze efekty słuchowe, funkcjonując w dwóch implantach niż tylko w jednym. Umiejętności językowe nabywane są w toku systematycznej rehabilitacji, a efekt końcowy związany jest również z wiekiem słuchowym dziecka, poziomem jego zdolności poznawczych i motywacji do mówienia. Możliwość długoletniego dostępu do języka mówionego na drodze słuchowej, wsparta funkcjonowaniem w dwóch implantach, daje m.in. szansę na zminimalizowanie bariery fonetycznej, z którą dzieci z głuchotą prelingwalną muszą się zmagać z racji swojej niepełnosprawności. Wzrost umiejętności doskonalszej lokalizacji dźwięków oraz poprawa rozumienia mowy w szumie dzięki

7 Z.M. Kurkowski, Mowa dzieci sześcioletnich z uszkodzonym stuchem, Wydawnictwo UMCS, Lublin 1996, s. 60-70. 
bilateralnej implantacji dodatkowo dodaje dzieciom odwagi do językowego zaistnienia w grupie rówieśniczej, redukuje lęk związany $\mathrm{z}$ komunikacją $\mathrm{w}$ warunkach niekomfortowych akustycznie, daje im wiarę $\mathrm{w}$ to, że mogą rozumieć innych i być zrozumianym przez innych. Chętniej inicjują kontakty oparte na komunikacji językowej oraz lepiej sobie radzą $\mathrm{w}$ sytuacjach, gdy wymagana jest szybka reakcja językowa na bodźce odebrane na drodze słuchowej.

\section{Dyskusja}

Analizując uzyskane wyniki badań, zaobserwować można, że dzieci użytkujące równocześnie dwa implanty lepiej sobie radzą słuchowo i językowo $w$ sytuacjach niekomfortowych akustycznie, niż przebywając $w$ takim samym środowisku i mając do dyspozycji tylko jeden implant. Czas użytkowania wszczepu również ma niebagatelny wpływ na poziom indywidualnych kompetencji językowych. Im jest on dłuższy, tym lepsze kompetencje językowe, tym bogatszy zasób pojęć i słownictwa. Jeżeli dziecko jest użytkownikiem dwóch wszczepów ślimakowych, mamy do czynienia z binauralną stymulacją drogi słuchowej oraz ośrodków słuchowych, co wpływa pozytywnie na funkcjonowanie $\mathrm{w}$ środowisku akustycznym i osiąganie lepszych wyników $\mathrm{w}$ zakresie rozumienia mowy na drodze słuchowej w każdych warunkach, a w konsekwencji skuteczne porozumiewanie się z innymi. Głównym celem pooperacyjnej rehabilitacji w ramach Programu Leczenia Głuchoty Metodą Wszczepów Ślimakowych jest stymulowanie rozwoju dziecka we wszystkich sferach rozwojowych, ze szczególnym uwzględnieniem sfery mowno-językowej i słuchowej. Wyniki przeprowadzonych badań w podobnych ośrodkach na świecie pokazują, że nabycie mowy i języka i wykorzystanie tych umiejętności w kontaktach międzyludzkich przez dziecko z głuchotą prelingwalną, zaimplantowane wszczepem ślimakowym jest możliwe ${ }^{8}$.

8 A.E. Geers, Speech and language evaluation in aided and implanted children, "Scandinavian Audiology" 1997, 26, s. 72-75. 
Wielu lingwistów uważa, że każdy człowiek posiada genetycznie uwarunkowaną, naturalną zdolność do opanowania procesów językowych i reguł gramatycznych, obowiązujących w języku danej społeczności ${ }^{9}$. Warunkiem koniecznym do ujawnienia się tychże jest zmysłowy dostęp do dźwięków, a co za tym idzie, przebywanie $\mathrm{w}$ środowisku, $\mathrm{w}$ którym zachodzi wiele procesów akustyczno-fonetycznych. Wszczep ślimakowy warunkuje prawidłowy przebieg procesów recepcji i percepcji dźwięków, czego w przypadku głębokich niedosłuchów powstałych $\mathrm{w}$ okresie prelingwalnym aparatowanie klasyczną metodą nie może zagwarantować ${ }^{10}$. Wczesna implantacja daje szansę na naturalny rozwój słuchu, mowy i języka w granicach normy fizjologicznej. Im młodsze dziecko, tym większa szansa na samodzielne odkrywanie i opanowanie języka społeczności, w której się wzrasta11. Maite Molina i współautorzy zauważyli, że im dłuższy czas użytkowania implantu i zarazem pooperacyjnej rehabilitacji, tym większa umiejętność wykorzystania informacji słuchowych odbieranych przez implant ${ }^{12}$. Obserwacje te są zbieżne z wynikami, które uzyskały dzieci implantowane w ośrodku poznańskim. Komfortowy odbiór mowy na drodze słuchowej oraz rozumienie słyszanych wypowiedzi uwarunkowane jest stażem użytkowania wszczepu, ale również wpływ na to może mieć jakość słyszenia $w$ jednym i w dwóch implantach. Sarant i współautorzy dostrzegają istotną różnicę $\mathrm{w}$ jakości słyszenia $\mathrm{w}$ warunkach uciążliwych akustycznie, czyli takich, w których wszyscy słyszący ludzie

${ }^{9}$ I. Kurcz, Psychologia języka i komunikacji, WSiP, Warszawa, 2000; Shugar G., Dziecko uczestnikiem dialogu w świetle badań z psycholingwistyki rozwojowej, "Nowiny psychologiczne" 1996, s. 3.

${ }^{10}$ M. Kawczyński., W. Szyfter i wsp., Postępy w rozwoju stuchowej percepcji mowy $u$ dzieci zaimplantowanych wszczepem ślimakowym w różnych grupach wiekowych, "Pediatria Polska", LXVII, nr 8, s. 669-673.

11 A.F.M. Snik, M.J.A. Makhdoum i wsp., The relations between age at the time of cochlear implantation and long term speech perception abilities i congenitally deaf subjects, "International Journal of Pediatric Otorhinolaryngology" 1997, 52, s. 214-217.

12 M. Molina, A. Huarte, Development of speech in 2- years- old children with cochlear implant, "International Journal of Pediatric Otorhinolaryngology” 1999, 47, s. 177-179. 
egzystują, gdy dźwięki nakładają się wzajemnie na siebie, na korzyść dzieci bilateralnie zaimplantowanych.

Wyniki badań przeprowadzonych wśród dzieci implantowanych w ośrodku poznańskim wykazują zbieżność z obserwacjami przedstawionymi powyżej ${ }^{13}$. Badane dzieci zaimplantowane bilateralnie w trybie sekwencyjnym i użytkujące wszczepy przez dłuższy czas (cztery i więcej lat) przejawiają kompetencje językowe, które choć zazwyczaj odbiegają od normy językowej przyjętej dla określonego wieku fizjologicznego u dzieci prawidłowo słyszących, nadal dynamicznie się rozwijają. Dwa sprawnie działające implanty ślimakowe dają pewność, że dziecko odnajdzie się słuchowo i językowo - na miarę swoich możliwości - w każdym środowisku akustycznym, w ciszy i w hałasie ${ }^{14}$.

Mimo dużej świadomości społecznej dotyczącej problematyki głuchoty i konsekwencji wynikających z tej niepełnosprawności, nadal konieczna jest edukacja środowisk, które mogą mieć wpływ na jakość wiedzy przekazywanej bliskim osób, które są zainteresowane Programem Chirurgicznego Leczenia Głuchoty Metodą Wszczepów Ślimakowych. Rodzice dzieci niesłyszących i niesłyszący, dorośli pacjenci, którym dostarczy się rzetelnej, merytorycznej wiedzy o możliwościach, ale i o ograniczeniach związanych z użytkowaniem wszczepu ślimakowego, będą mieli dzięki temu większą możliwość dokonywania świadomych wyborów, które mogą zmienić ich życie.

\section{Wnioski}

1. Proces rozwoju mowy i języka oraz percepcji słuchowej $\mathrm{u}$ dzieci zaimplantowanych bilateralnie $\mathrm{w}$ trybie sekwencyjnym podlega ciągłemu doskonaleniu.

13 J. Sarant, D. Harris., op. cit., s. 396-409.

${ }^{14}$ R.M. Reeder, J.B. Firszt i wsp., Acongitudinal study in children with sequential bilateral cochlear implants: Time course for the Second Implanted Ear and Bilateral Performance", "Journal of Speech Language and Hearing Research" 2017, Jan. 1, 60(1). 
2. Poziom rozwoju mowy i kompetencji językowych związany jest m.in. z czasem użytkowania implantu ślimakowego.

3. Dzieci bilateralnie zaimplantowane w trybie sekwencyjnym, użytkujące dwa sprawne implanty wykazują lepszą orientację słuchową w różnych środowiskach akustycznych, nie zawsze komfortowych niż w analogicznych warunkach z jednym wszczepem.

\section{Bibliografia}

Geers A.E., Speech and language evaluation in aided and implanted children, "Scandinavian Audiology" 1997, 26.

Kawczyński M., Szyfter W. i wsp., Postępy w rozwoju stuchowej percepcji mowy u dzieci zaimplantowanych wszczepem ślimakowym w różnych grupach wiekowych, „Pediatria Polska", LXVII, nr 8.

Kurcz I., Psychologia języka i komunikacji, WSiP, Warszawa, 2000; Kurkowski Z.M., Mowa dzieci sześcioletnich z uszkodzonym stuchem, Wydawnictwo UMCS, Lublin 1996.

Molina M., Huarte A., Development of speech in 2- years- old children with cochlear implant, „International Journal of Pediatric Otorhinolaryngology” 1999, 47.

Reeder R.M., Firszt J.B. i wsp., Acongitudinal study in children with sequential bilateral cochlear implants: Time course for the Second Jmplanted Ear and Bilateral Performance", "Journal of Speech Language and Hearing Research" 2017 Jan. 1, 60(1).

Sarant J., Harris D., Bennet L., Bant S., Bilateral versus unilateral cochlear implants in children: a study of spoken language outcomes, „Ear Hear” 2014 Jul.-Aug., 35(4).

Skarżyński H., Wszczepy ślimakowe, [w:] Zarys audiologii klinicznej, red. A. Pruszewicz, Poznań 2000, 2.

Shugar G., Dziecko uczestnikiem dialogu w świetle badań z psycholingwistyki rozwojowej, "Nowiny psychologiczne", 1996.

Smith A., Umyst, PZWL, Warszawa 1989.

Snik A.F.M., Makhdoum M.J.A. i wsp., The relations between age at the time of cochlear implantation and long term speech perception abilities i congenitally deaf subjects, "International Journal of Pediatric Otorhinolaryngology" 1997, 52.

Szagun B., The acquisition of grammatical and lexical structures in children with cochlear implants: a development psycholinguistic approach, "Audiology and Neurotology" 2000, 5.

Szyfter W., Pruszewicz A., Woźnica B. i wsp., Ocena zachowań stuchowych dzieci postugujących się wszczepem ślimakowym, "Otolaryngologia Polska” 1997, Tom L, Supl. 22.

Szyfter W., Kaczmarek J. i wsp., Czy mnogie uszkodzenia uniemożliwiaja zastosowanie wszczepów wewnątrzślimakowych, Rehabilitacja w Otologii Materiały zjazdowe I Międzynarodowego Sympozjum Naukowego, Poznań, 8-10.10.1998. 